Saxenian, A. (1994), Regional advance, culture and competition in Silicon Valley and Route 128, Cambridge, Harvard University Press,.

Schmookler, J. (1962), “Economic Sources of Inventive Activity", Journal of Ecomomic History. XXII (1), pp. 1-20.

Schumpeter, J. (1912), Theorie der wirtschaftlichen Entwicklung, Berlín, Duncker \& Humblodt.

(1934), The theory of economic development, Harvard University Press, Cambridge, Massachusetts.

(1942), Capitalismo, socialismo y democracia, J. Díaz (trad.), Madrid, Aguilar.

Scott, C.; Brown, J. (1999), "Bridging epistemologies: The generative dance between organizational knowledge and organizational knowing". Organization Science 10, pp. 381-400.

Shapiro, C., y H. Varian, (1998), Information rules: a strategic guide to the network economy, Harvard Business School Press, Boston, Massachusetts.

Stuart, T., y J. Podolny (1996), "Local search and the evolution of technological capabilities”, Strategic Management Journal, núm. 17, pp. 21-38.

Teece, D. (1986), "Profiting from technological innovation: implications for integration, collaboration, licensing and public policy", Research Policy, 15(6), pp. 285 305.

(1989), "Interorganizational requirements of the innovation process", Managerial and Decision Economics, 10 (1), pp. 35-42.

Villaseca, J., y J. Torrent (2008), “TIC, conocimiento y crecimiento económico. Un análisis empírico, agregado e internacional, sobre las fuentes de la productividad", Economía Industrial, 360, pp. 41-60.

Von Hippel, E. (1986), "Lead Users: A source of novel product concepts", Management Science, 32 (7), pp. 791-805.

West, J., y S. Gallager, (2006), "Open Innovation: A New Paradigm for Understanding Industrial Innovation”, en H. Chesbrough; W. Vanhaverbeke; J. West (comps.), Open Innovation: Researching a New Paradigm, Nueva York, Oxford University Press, pp 82-106.

Yin, R. (2003), Case Study Research: Design and Methods, California, Sage.

\section{A Microeconometric Analysis on the Pension Reforms in Argentina, Bolivia, Mexico and Uruguay}

Roberto Gallardo del Ángel*

\section{AbSTRACT}

This paper contains information about workers' participation in the pension schemes in four Latin American countries which carried out structural pension reforms in 1990's. I surveys some interesting hypotheses about the main causes that discourage participation in the new pension scheme. The main finding is that the present participation structure is strongly influenced by labor market characteristics like low-productivity and informal jobs.

Classification number: JEL: J26, J32.

Key words: pension reform, substitutive reforms, mixed reforms, private pensions, retirement policies.

\section{RESUMEN}

Este artículo contiene información sobre la participación de los trabajadores en el sistema de pensiones en cuatro países de América Latina, en los que las pensiones experimentaron reformas estructurales en 1990. Analiza algunas hipótesis interesantes sobre las principales causas que desalientan la participación de los trabajadores en el nuevo régimen de pensiones. El principal hallazgo es que la estructura de la participación actual está fuertemente influida por las características del mercado laboral, así como por la baja productividad y el empleo informal.

Número de clasificación: JEL: J26, J32.

Palabras clave: reformas en las pensiones, reformas sustitutivas, reformas mixtas, pensiones privadas, políticas de jubilación.
* Profesor de la Facultad de Economía de la Universidad Veracruzana. Correo electrónico: rogallardo@uv.mx. 


\section{INTRODUCTION}

In Latin America, country Governments failed to ensure universal access to pensions. After more than four decades of pension systems in Latin America the prereform situation in 1980's were a dispersed, poor managed, unfair and strongly Bismarckian public pension schemes. Then, a new era of reforms came to light in early 1990's and almost all Latin American Government established a new private pension pillar that was thought to be more attractive for all workers. ${ }^{1}$

The long term fiscal sustainability of the public pension schemes was severely questioned in Latin America during 1990's. The pension scheme had several difficulties including large public deficits. Some countries began to carry out important reforms to their old PAYGO (pay-as-you-go) pension schemes. Many of them opted for structural reforms and created a new private pension pillar, privatizing management and reforming the entire institutional framework. Some of them went further and eliminated the entire public system, then abandoning the solidarity and redistributive principles of the old scheme.

Pension reforms of 1990's in Latin America were characterized by one important structural change: the creation of a new private pillar of contribution; in simple words, a private pension system. This new private scheme in some cases substituted completely the old public PAYGO regime or complemented it through a multi-pillar system.

In the words of Mesa-Lago (2005): "structural reforms are those that replace on the whole or in part the public system with a private one". He divided these structural pension reforms into three types:

1) The substitutive reform: The old PAYGO public system is substituted completely by the fully funded privately managed scheme. Chile, Mexico, Bolivia, El Salvador, República Dominicana and Nicaragua adopted this scheme.

2) The mixed reform: The fully-funded privately-managed scheme complements the old-public PAYGO. Examples are Argentina, Uruguay, Costa Rica and Ecuador.

${ }^{1}$ James (1997) stated: "The close linkage between benefits and contributions, in a defined-contribution plan, is designed to reduce labor market distortions, such as evasion by escape to the informal sector, since people are less likely to regard their contribution as a tax".
3) The parallel reform: The second pillar competes with PAYGO scheme and the individuals are allowed to join one scheme only. Only Peru and Colombia have carried out such reform.

The remaining countries have not yet carried out any reform or are implementing parametric reforms which are adjustments to the old PAYGO to produce realistic actuarial predictions and improve the long-term financial viability. ${ }^{2}$

The first three reforms above are known as "structural reforms". The difference between parallel and mixed reform is that in the parallel reform individuals are only allowed to participate in one pillar, either the public PAYGO or the private fully funded, but both those systems are considered as one having multi-pillars.

The structural pension reforms brought another important change: the elimination of the Bismarckian aspects of the pension schemes in the region. Before the reforms only salaried workers or within-firm workers were able to get pensions. Then, one main objective of the pension reforms was to remove the entrance barriers for participation in the entire system. Many legal restrictions were eliminated in order to encourage enrollment. The reforms opened the door to all individuals no matter whether their status is salaried-formal worker or not.

The main aim of this work is to test some important hypothesis related to workers' preference for the new pension scheme. The econometric analysis was constructed in order to inspect some propositions related to the labor conditions of individuals. Pension coverage has strong links with formal labor conditions and the transition from informal to formal activities implies high costs and welfare lost which might be not fully compensated with future pension benefits.

Labor incentives and productivity also produce a change in preferences in workers' life-time portfolio of savings which may encourage them to include pensions. The new reforms may not produce any significant change in coverage unless better labor conditions and better social risk management instruments were enforced. Some disincentives may be found in traditionally low-productive sectors like construction, agriculture or transportation.

Despite the "attractiveness" of the private pension schemes, it is sometimes difficult to unite theoretical work and reality. Feldstein and Ranguelova (2001) are strong proponents for the new private scheme. They show that a private pension scheme is indeed more attractive and may offer higher returns than

\footnotetext{
${ }^{2}$ Increase in contributions and retirement ages were among the usual policy instruments for this
} parametric reform. 
the public pension fund, but still the public scheme is the larger provider of pensions in USA. Many Latin American countries have adopted the new private pillar, still enrollment and effective contribution is relatively low. Only Chile has an effective participation little over $60 \%$ which is the highest among Latin American countries.

Even though private pension funds managers offer higher returns, workers must bear the entire financial risk and the management costs which in some cases are significant. Most theoretical models justify an efficient outcome considering only the higher returns of private annuities (see Abel, 1986), but there are many other considerations to take into account. There are more complications when trying to analyze workers' decisions in Latin America because labor markets are rigid and the institutional base is weaker.

\section{RELATED WORKS}

From the theoretical point of view, pensions are linked to the labor supply through the equalizing differences ${ }^{3}$ approach. Pensions are a kind of non pecuniary income and are used for compensating income late in life. Workers may be willing to receive lower monetary wages or salaries if they are compensated with other income in kind like health insurance, pensions or other fringe benefits. The theory of equalizing differences is a starting point for the research on different jobs and compensation packages. Pensions are part of the compensation package and strongly linked to labor market conditions. Rosen (1986, pp. 641-642) stated: "Measurable job attributes on which compensating wage differentials have been shown to arise empirically include: ... (iv) the composition of pay package, including vacations, pensions, and other fringe benefits as substitutes for direct cash wage payments".

But this theory is insufficient to explain the entire Latin American reality. This theory assumes that labor markets always clear and there are sufficient number of formal jobs offering pensions. The new pension schemes allow workers to contribute voluntarily and pensions are not necessarily part of the job contract anymore. Then the compensation package is becoming more diverse and the trade-off between informal and formal jobs is perhaps small in some coun-

${ }^{3}$ The compensating wage differences were first discussed by Adams Smith (1776) in his celebrated book An inquiry on the nature and cause of the wealth of nations, chapter X. But the formalization of this theory was possible thanks to Sherwin Rosen (1986). tries with large underdeveloped and outdated technology sectors. This theory can only explain part of problem but unquestionably it is a powerful tool for microeconomic analysis.

Informal labor may be accepted as a different kind of labor supply, but there is not a formal theory to model this kind of labor with pensions. Real world data shows that informal workers do prefer monetary wages more than any other non pecuniary wages like pensions. So it seems to be a inverse relation between informal labor supply and pensions. So the hypothesis that informal workers are less likely to participate in the new pension scheme will also be tested in this analysis.

The objective of this empirical testing is to estimate the marginal effect of some selected and harmonized sets of variables which contain information about the individual and labor market characteristics of the labor force. The dependent variable will be the contribution to the new pension scheme. This analysis is applied to the labor force which is divided in two large groups: salaried and independent workers.

Our empirical analysis follows the works of De la Rica and Lemiuex (1993), Auerbach et al. (2005) and Holzmann, Packard and Cuesta (2001) though we constructed a slightly different model, using different variables and data sources.

De la Rica and Lemieux (1993) is an empirical analysis on individua participation closely related to this work. This is a study about participation of workers in the social security in US and Spain. These authors use the "theory of equalizing differences" to explain the demand for health insurance. They also use a PROBIT analysis to test the rationale of workers to demand health insurance from their employers.

Auerbach et al. (2005) is also a similar work on social security in Latin America using PROBIT and LOGIT model testing. This is a microeconomic analysis on the participation of workers in social security in Latin America. They do not test for pensions directly rather they analyze the overall contribution to social security network which also includes health insurance, survivor insurance, disability grants, etc. The main difference with this dissertation is that we analyze exclusively the rationale for participation in the new pension schemes rather than the whole social security system.

Holzmann, Packard and Cuesta (2001) is an interesting microeconomic analysis on the participation in the pension system. ${ }^{4}$ They proposed several hy-

\footnotetext{
${ }^{4}$ This paper was included in Holzmann and Stiglitz (2001).
} 
pothesis on the rationale for participation in the new pension schemes. They used the household income surveys (HIS) of Chile and Argentina and carried out PROBIT regression methods to test some propositions. The scope of Holzmann, Packard and Cuesta (2001) is limited to two countries and their methodology and objectives are essentially different to our dissertation. Our analysis is also an assessment on the rationale for participation but we test separately salaried and independent workers. Another important difference is that the final objective is to sample two types of pension reforms: mixed and substitutive reforms. Mexico and Bolivia offer some evidence for the substitutive pension scheme while $\mathrm{Ar}$ gentina and Uruguay offer some information about the mixed reforms. Then, our work is mainly a harmonization process in order to obtain results as comparable as possible. We focused on those countries that carried out pension reforms in 1990 's and are relatively new reforms compared to the mature Chilean reform. Another important feature is that individual preferences are tested after a similar period of time from the reform in every country.

\section{THE DATA}

Latin America is a continent with strong social contrasts and different level of institutional quality. These differences also affect the quality of the household surveys and our data sets. The experience of macro and micro data management is different across countries. Four household income surveys (HIS) were used for construction of more than twenty dummies and other independent variables. Every country survey has different structure and objectives, making complete harmonization a difficult task. The information in every data set may contain bias due to poor survey design, implementation and data management. It is difficult to assess how much this bias is present, but an effort was made to try to close the gap and construct some imperfect variables and dummies to test our work.

The whole experiment can be better explained if we describe our universe of analysis. This analysis includes the whole labor force from the household surveys of four countries. We do not include those individuals that are not actively participating in the labor market like students, retirees, house-wives and other dependants. The whole labor force is divided in two groups for study: salaried and independent workers. The total sample in each country goes from 22000 in Uruguay up to more than 36000 in Mexico. The appendix 1 contains the main features of the data sets.
The data for Uruguay comes mainly from the metropolitan area of Montevideo. Uruguay is a small country and the population is heavily concentrated in one main urban area. The main reason to design an urban survey comes from the population structure of Uruguay where the urban population is about $92 \%$ of the total

The Mexican data is a nation-wide survey that includes urban and rural areas. This is quite understandable due to the size and dispersion of the population in Mexico where only $76 \%$ of the population lives in urban areas. Mexico still has large sectors of population living in rural areas and then this data represents better this country's reality.

The data from Argentina includes the urban population in 35 small and large cities. This is also understandable because $90 \%$ of the population in Argentina lives in urban areas. The Argentinean HIS is a longitudinal data used designed for panel studies. The major problem in the Argentinean data is the lack of information about independent workers perhaps due to design problems. The regression analysis was possible for salaried workers only.

The Bolivian data comes from a combined 2003 and 2004 survey. The data set is a country wide survey due to the fact that only $64 \%$ of the Bolivian population lives in urban areas. The structure of the Bolivian survey is less extensive compared with other countries. The information about economic sectors is not numerical and it had to be transformed into numerical values in order to construct the dummy variables. This survey also does not allow testing for independent workers. The reason may be that Bolivian economic reality shows that independent workers are indeed not participating in the new pension scheme.

\section{EFFeCtive COVERAGE AND BENEFITS}

In order to understand the rationale for participation in the new pension scheme we must observe the level of effective contribution. ${ }^{5}$ The evidence from different sources shows that, after the reforms effective contribution in the pension system has not increased. Table 1 gathers information mainly from Mesa-Lago (2001) on effective coverage before and after the reforms in some Latin American countries.

From the individual point of view, another element which can be used as an indicator of the relative success of a pension reform is the relative size of ben-

${ }^{5}$ Effective contribution is the total number of workers that effectively and regularly pay their pension tax or contribution. This is different for the concept of "enrollment" which is usually larger. 
Table 1. Effective Coverage and Benefits in some Latin American Countries

\begin{tabular}{|l|c|c|c|}
\hline \multirow{2}{*}{ Country } & Average Benefits & \multicolumn{2}{|c|}{ Entire System (Public and Private) } \\
\cline { 3 - 4 } & (PPP dollars of 2002) & Before the Reform & 2002 \\
\hline Argentina & 426.07 & $50 \%$ & $24 \%$ \\
Bolivia & 686.98 & $12 \%$ & $11 \%$ \\
Chile & 333.39 & $64 \%$ & $58 \%$ \\
Mexico & 368.16 & $37 \%$ & $30 \%$ \\
Uruguay & 329.06 & $73 \%$ & $60 \%$ \\
\hline
\end{tabular}

Source: Mesa-Lago C. (2005) in Crabbe C. (2005).

efits. As the new private pillar is intended to become the main provider of benefits in the future, the expected return and the pension benefits are extremely important.

Using Chile as the benchmark for comparison, the figure 1 shows the size of pension benefits in the present schemes in some Latin American countries using international dollars (Purchasing Power Parity).

Present generations under the old PAYGO schemes are receiving benefits relatively high thanks to generous vesting conditions and favorable legislation. Many retirees associations, labor unions, public officials and other political groups lobby for better retirement conditions, making difficult to the government to apply better actuarial corrections. This is perhaps evident in countries with poor and weak institutions.

Bolivia's pension benefits fluctuate abruptly during the early stages of the pension reforms and increased after the basic universal pension ${ }^{6}$ Bonosol began to be paid. This basic benefit is paid to all retirees whether they are participants in the pension scheme or not. In this way, those participants in the pension scheme may receive additional benefits from the Bonosol increasing the replacement rate. This is the reason why the pension benefits increased suddenly after the reform.

${ }^{6}$ The concept of "basic universal pension" should no be confused with the term "minimum pension" or "minimum benefit". The Bonosol is a basic pension for all Bolivians and its amount depends in the resources available in the specific pension fund. The minimum pension is usually a guarantee for those workers that cannot get enough savings for retirement in the private pillar. This minimum pension is a minimum retirement consumption limit imposed by the government and must be paid from general fiscal revenue.
Figure 1. Average Pension Benefits in some Latin American Countries

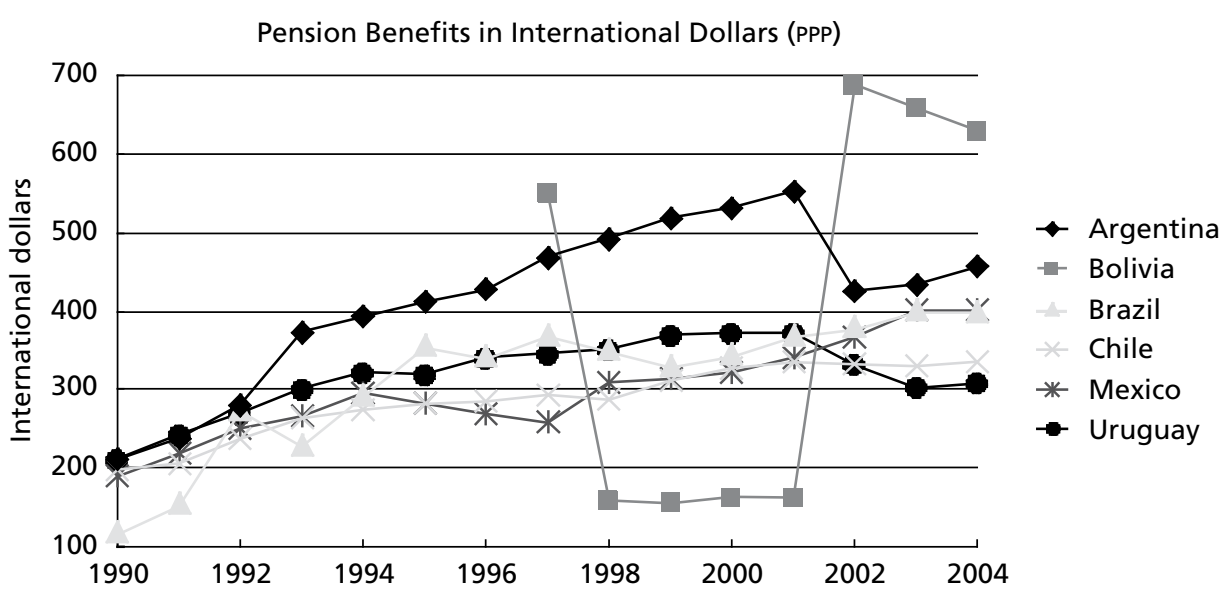

Note: For Argentina, Brazil, Bolivia, Mexico and Uruguay is the present average benefit in the public scheme. For Chile is the present average benefit paid by the Retirement Funds Management Agencies.

Source: Own elaboration with data from: International Monetary Fund (IMF). Bank of Social Security of Uruguay (BPS). Ministry of Social Protection of Brazil. Ministry of Labor, Employment and Social Security of Argentina. Department of Retirement Funds Management Agencies of Chile. Sixth Presidential Report of Mexico.

The average pension benefit in Argentina and Uruguay collapsed after the Argentinean peso crisis of 1999-2002. The average benefit in Uruguay does not include those pensions in the independent pension fund trusts (cajas de pensiones). The workers in these fund trusts may have higher education and enjoy larger benefits, which may increase the Uruguayan average benefit and make it close or exceed the Chilean average. On the other hand, Mexico's PAYGO pension benefits are high and well above the fully funded benefit paid in Chile.

The Chilean reform rendered in average real returns over $10 \%$ during the last 25 years. But perhaps the most attractive feature of the Chilean pension scheme is its stability over time. Using the standard deviation to analyze the volatility in the value of pension benefits we observe that the Chilean scheme is the most stable system, followed by Mexico and Uruguay. The standard deviation of Brazil and Argentina is twice that of Chile, and the Bolivian is six times larger. In some respects a second pillar may bring more stability to the system, because the benefits are not linked to political decisions and lobbying.

Coverage level is not even in every country and the perception that a fully funded scheme or an actuarially fair scheme may increase participation is 
incomplete because it does not consider additional costs and disincentives, especially for those poor and informal workers.

\section{Individual Preferences}

In this section we evaluate the results from our empirical testing, looking at the individual and labor market characteristics that may influence participation in the new pension schemes in four countries: Argentina, Bolivia, Mexico and Uruguay. As we mentioned above, these countries are examples of two types of pension reforms: substitutive and mixed reforms. This allow us to draw conclusions about two types of reforms, one with a public pillar and other without it.

Argentina and Uruguay were used to analyze individual preference for pensions in a mixed scheme while Mexico and Bolivia were used for the substitutive reform. The main difference between these two types of structural reforms is the use or exclusion of the old public scheme.

What is most absorbing puzzle is that the public pension is maintained in countries where aging population is a major problem like in Argentina and Uruguay. On the other hand, countries with relatively young populations are eliminating completely the public system. The potential support ratio in Argentina was about 6.2 persons in working age ( 15 to 64 years old workers) per one elderly in 2005 and Uruguay has a ratio of 4.6, little better or similar to the European and North American's demographic structure. In the other hand, Mexico and Bolivia had a potential support ratio above 10 in 2005.

From the theoretical stand point this is a puzzling situation. Countries with aging population problem might have lower returns in the public scheme, making the private one more attractive. The rational choice would be to implement substitutive reforms in Argentina and Uruguay, but these countries, with a lower population growth rate, still maintain the public pension scheme in their systems.

We take a look at the rationale of participation in every country in order to find common features between two types of reforms. Appendixes 1 to 5 contain the PROBIT parameters of the independent variables from the harmonized data sets in marginal effects.

Most parameters are highly significant. Every regression was performed up to four times omitting some variables that might bring multicollinearity into the analysis. The most frequent source of this problem was the correlation between informality and low wages, which means that most low income workers are also informal. Nevertheless we may also find informality in all income groups

The proxy we used to test for informality in Argentina, Mexico and Bolivia was the legal contract ${ }^{7}$ status in every job. All workers with a legal bound are considered formal. The only exception is Uruguay where this information was not available and we used the concept of underemployment. All parameters for informality and underemployment are negative and highly significant which show the strong link between the condition of formal worker and pension coverage. Even though the pension reforms opened the doors to all individuals, many informal workers still found themselves outside the pension scheme. But in most cases, salaried-informal and independent-informal workers find optimal stay out the pension system and avoid participation.

Participation of independent workers is less probable than salaried workers because many independent workers in Latin America are small business with outdated technology and low productive methods. These workers usually are informal and have higher transition costs and do not find attractive to join the pension scheme. In the other hand, high-income independent workers do enjoy a more diversified portfolio with better investment instruments and higher returns.

Substitutive reforms were implemented in countries where the relative influence of informality is strong. One preliminary result from the analysis of salaried workers is that labor characteristics like informality are more influential in substitutive reforms than in mixed reforms. Bolivia and Mexico have the largest absolute marginal effects.

The variable of informality for Uruguay uses the concept of underemployment, showing a smaller absolute marginal effect compared with Argentina, Bolivia and Mexico. This is in part due to different information captured by the imperfect dummy variable which underestimates the total effect of informality.

Differences in productivity are also important and reflect the possibility of participation in the pension scheme. Labor characteristics are different among salaried workers. The marginal changes in sectors where formal employment is high are positive like in manufacturing. Manufacturing workers in medium size and large companies are usually unionized and enjoy pensions and other fringe benefits.

Sectors with large groups of informal workers and using outdated technology, like construction, have small or negative marginal changes. Other less

${ }^{7}$ A similar proxy of informality was constructed by Holzmann, Packard and Cuesta (2001). 
productive sectors like agriculture and retail sales also have negative parameters Analogously, informal activities are widespread in these sectors also. The Latin American reality shows that many poor and informal workers find occupation in agriculture, construction or retail sales.

There is a strong correlation between informal workers and those workers earning less than a minimum wage. The preliminary evidence from four countries suggests different behavior between salaried and independent workers. But still the rationale for poor and informal workers, either salaried or independent, is to stay out of the new pension scheme.

The analysis shows that participation in the pension scheme increases as the retirement age approaches. Younger workers are less risk averse and take over more risky enterprises. In Bolivia the marginal effect for older workers is lower than for younger ones. The reason behind might be that the Bolivian pension scheme is relatively small and only few young workers with enough human capital may be considered for enrollment.

An important variable that increases participation in the pension scheme is education. The marginal effect is always positive for workers with tertiary level of education. The change from elementary to tertiary education is usually large and shows that an increase in training and education is important and may produce positive changes in coverage. Education and informality (or workingpoor condition) are perhaps the most important factors to be considered when designing pension policy.

Another comment on the regression results is that the marginal effects for Argentina are usually positive and higher than other countries. Holzmann, Packard and Cuesta (2001) had already mentioned the fact that results for independent workers could not be obtained from the Argentinean household survey. Our assessment is that this longitudinal survey has an important bias toward salaried workers. The reason is that this survey was designed to trace a stable sample of salaried workers in order to produce a set of panel data. This objective may not be achieved if we include in the sample a large proportion of independent workers, a group that has higher mobility and is more difficult to observe.

\section{FinAL CONSIDERATIONS}

The above results illustrate the fact that the pension policy must be designed to meet the needs of different sectors and groups of workers, and to meet the expectations of a diverse labor force.

The pension reforms also contain many political and practical considerations which are different in every country. It may be difficult to assess all economic, social and political implications at once. Administration and transition costs of the entire system must also be considered when evaluating the advantages of the new private pillar over the public one. The complexity of every pension scheme forced different strategies in every reform.

There are some factors that may reduce the return and benefits in the private system. Imperfect competition in the pension industry, high management costs, financial risks, and economic depression among others are some of these factors. These conditions are very dynamic and change from one generation to another, making difficult to estimate future value of the benefits. Although the private scheme seems to be better insulated against lobbying, poor management and other political risks, the preliminary evidence shows that a more diversified pension scheme may also be a good way to provide pension benefits.

Our results show that the condition of formal job and productivity of certain sectors are important consideration for pension policy. Informal and less productive workers still do not find attractive to join the new pension schemes. The results from our empirical testing show that the there is a strong negative relation between informal labor supply and preference for pensions. Perhaps the pension fund manager and policy makers should pay closer attention to those workers with low income and higher transaction costs rather to. 


\section{APPENDIX 1}

Main Characteristics of the Data Used for Empirical Testing

\begin{tabular}{|l|l|c|c|c|c|}
\hline Country & Name of the Survey & Years & $\begin{array}{c}\text { Observations } \\
\text { Included }\end{array}$ & Coverage & $\begin{array}{c}\text { Panel } \\
\text { Data }\end{array}$ \\
\hline Argentina & $\begin{array}{l}\text { Encuesta Permanente de } \\
\text { Hogares }\end{array}$ & 2001 & 32.238 & Urban areas & Yes \\
\hline Bolivia & $\begin{array}{l}\text { Encuesta Continua de } \\
\text { Hogares }\end{array}$ & $\begin{array}{c}2003 \text { and } \\
2004\end{array}$ & 25.205 & Country wide & No \\
\hline Mexico & $\begin{array}{l}\text { Encuesta Nacional de } \\
\text { Ingresos y Gastos de los } \\
\text { Hogares }\end{array}$ & 2004 & 36.575 & Country wide & No \\
\hline Uruguay & $\begin{array}{l}\text { Encuesta Continua de } \\
\text { Hogares }\end{array}$ & 2002 & 22.116 & Urban areas & No \\
\hline Peru & $\begin{array}{l}\text { Encuesta Nacional de } \\
\text { Hogares }\end{array}$ & 2000 & 4.145 & Country wide & No \\
\hline
\end{tabular}

Note: The total observations represent only the labor force.

\section{APPENDIX 2.1}

Standard Statistics.

Salaried Workers in Argentina, 2001

\begin{tabular}{|l|c|c|}
\hline Variable & Mean & Std. Dev. \\
\hline Pension & 0,6167 & 0,4862 \\
\hline Male & 0,5677 & 0,4954 \\
\hline Married & 0,4580 & 0,4982 \\
\hline Age 14-24 & 0,1771 & 0,3817 \\
\hline Age 25-49 & 0,6512 & 0,4766 \\
\hline Age 50-65 & 0,1559 & 0,3628 \\
\hline Elementary & 0,2914 & 0,4544 \\
\hline Secondary & 0,1735 & 0,3787 \\
\hline Tertiary & 0,2859 & 0,4518 \\
\hline Agriculture & 0,0209 & 0,1429 \\
\hline Construction & 0,0607 & 0,2388 \\
\hline Retail & 0,1615 & 0,3680 \\
\hline Manufacture & 0,1054 & 0,3071 \\
\hline Energy & 0,0115 & 0,1065 \\
\hline Government & 0,1640 & 0,3703 \\
\hline Financial Services & 0,0654 & 0,2472 \\
\hline Education Services & 0,1109 & 0,3141 \\
\hline Health Services & 0,0639 & 0,2446 \\
\hline Informality & 0,1205 & 0,3255 \\
\hline Less 1 Ms & 0,1931 & 0,3947 \\
\hline 1to 2 Ms & 0,3610 & 0,4803 \\
\hline 2 to 3 Ms & 0,1921 & 0,3940 \\
\hline Log Income & 2,4433 & 0,7165 \\
\hline Hours & 41,0386 & 19,2985 \\
\hline
\end{tabular}




\section{APPENDIX 2.2}

PROBIT Estimates in Marginal Effects: Contribution to the New Pension Scheme. Salaried Workers in Argentina, 2001

\begin{tabular}{|c|c|c|c|c|c|c|}
\hline \multirow{2}{*}{$\begin{array}{ll} & \text { Variable } \\
\text { C }\end{array}$} & \multicolumn{2}{|c|}{ Regression A } & \multicolumn{2}{|c|}{ Regression B } & \multicolumn{2}{|c|}{ Regression C } \\
\hline & 0.3552 & $* * *$ & -0.7385 & $* * *$ & -0.7437 & $* * *$ \\
\hline & $(0.1269)$ & & $(0.0969)$ & & $(0.0549)$ & \\
\hline \multicolumn{7}{|c|}{ Gender and marital status } \\
\hline \multirow[t]{2}{*}{ Male } & 0.0728 & $* * *$ & 0.0990 & $* * *$ & 0.0990 & $* \star *$ \\
\hline & $(0.0252)$ & & $(0.0243)$ & & $(0.0243)$ & \\
\hline \multirow[t]{2}{*}{ Married } & 0.1135 & $* * *$ & 0.1339 & $* * *$ & 0.1341 & $\star \star \star *$ \\
\hline & $(0.0240)$ & & $(0.0232)$ & & $(0.0231)$ & \\
\hline \multicolumn{7}{|l|}{ Age } \\
\hline \multirow[t]{2}{*}{ Age 14-24 } & 0.0667 & + & -0.0056 & & & \\
\hline & $(0.0894)$ & & $(0.0868)$ & & & \\
\hline \multirow[t]{2}{*}{ Age 25-49 } & 0.1774 & $* * *$ & 0.1532 & $* * *$ & 0.1583 & $* * *$ \\
\hline & $(0.0858)$ & & $(0.0835)$ & & $(0.0286)$ & \\
\hline \multirow[t]{2}{*}{ Age $50-65$} & 0.2088 & $* * *$ & 0.2064 & $* * *$ & 0.2114 & $\star * \star \star$ \\
\hline & $(0.0892)$ & & $(0.0868)$ & & $(0.0390)$ & \\
\hline \multicolumn{7}{|l|}{ Education } \\
\hline \multirow[t]{2}{*}{ Elementary } & -0.0929 & $\star \star \star *$ & -0.1356 & $* * *$ & -0.1354 & 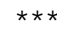 \\
\hline & $(0.0303)$ & & $(0.0291)$ & & $(0.0290)$ & \\
\hline \multirow[t]{2}{*}{ Secondary } & -0.0085 & & -0.0146 & & -0.0146 & \\
\hline & $(0.0337)$ & & $(0.0326)$ & & $(0.0326)$ & \\
\hline \multirow[t]{2}{*}{ Tertiary } & 0.0070 & & 0.0587 & $* * *$ & 0.0586 & $* \star *$ \\
\hline & $(0.0326)$ & & $(0.0314)$ & & $(0.0314)$ & \\
\hline \multicolumn{7}{|l|}{ Economic Activity } \\
\hline \multirow[t]{2}{*}{ Agriculture } & 0.3010 & $\star * *$ & 0.2924 & $* * *$ & 0.2923 & $\star \star \star *$ \\
\hline & $(0.0776)$ & & $(0.0739)$ & & $(0.0739)$ & \\
\hline \multirow[t]{2}{*}{ Manufacture } & 0.2776 & $* * *$ & 0.2983 & $* * *$ & 0.2983 & $\star \star \star *$ \\
\hline & $(0.0385)$ & & $(0.0375)$ & & $(0.0375)$ & \\
\hline \multirow[t]{2}{*}{ Construction } & 0.0883 & $* \star *$ & 0.0927 & $* * *$ & 0.0926 & $* * *$ \\
\hline & $(0.0477)$ & & $(0.0466)$ & & $(0.0466)$ & \\
\hline \multirow[t]{2}{*}{ Energy } & 0.4779 & $* * *$ & 0.5338 & $* * *$ & 0.5338 & $\star * * *$ \\
\hline & $(0.1266)$ & & $(0.1221)$ & & $(0.1221)$ & \\
\hline \multirow[t]{2}{*}{ Retail } & 0.2335 & $* * *$ & 0.2315 & $\star * *$ & 0.2314 & $\star * *$ \\
\hline & $(0.0335)$ & & $(0.0326)$ & & $(0.0326)$ & \\
\hline
\end{tabular}

\section{APPENDIX 2.2}

PROBIT Estimates in Marginal Effects: Contribution to the New Pension Scheme. Salaried Workers in Argentina, 2001

\begin{tabular}{|l|c|c|c|c|c|c|}
\hline \multicolumn{1}{|c|}{ Variable } & \multicolumn{2}{|c|}{ Regression A } & \multicolumn{2}{c|}{ Regression B } & \multicolumn{2}{c|}{ Regression C } \\
\hline Financial services & 0.3114 & $* * *$ & 0.3445 & $* * *$ & 0.3445 & $* * *$ \\
\hline & $(0.0466)$ & & $(0.0456)$ & & $(0.0456)$ & \\
\hline Government & 0.5116 & $* * *$ & 0.5386 & $* * *$ & 0.5386 & $* * *$ \\
\hline & $(0.0398)$ & & $(0.0379)$ & & $(0.0379)$ & \\
\hline Education services & 0.6572 & $* * *$ & 0.6633 & $* * *$ & 0.6634 & $* * *$ \\
\hline & $(0.0506)$ & & $(0.0483)$ & & $(0.0483)$ & \\
\hline Health services & 0.3895 & $* * *$ & 0.4043 & $* * *$ & 0.4044 & $* * *$ \\
\hline & $(0.0488)$ & & $(0.0473)$ & & $(0.0472)$ & \\
\hline Labor condition & & & & & & \\
\hline Informality & -0.4683 & $* * *$ & -0.5099 & $* * *$ & -0.5100 & $* * *$ \\
\hline & $(0.0393)$ & & $(0.0382)$ & & $(0.0382)$ & \\
\hline Income & & & & & & \\
\hline Less 1 MS & -0.8484 & $* * *$ & & & & \\
\hline & $(0.0643)$ & & & & & \\
\hline 1 to 2 MS & -0.3912 & $* * *$ & -0.0510 & $* * *$ & -0.0511 & $* * *$ \\
\hline & $(0.0360)$ & & $(0.0246)$ & & $(0.0246)$ & \\
\hline 2 to 3 MS & -0.1175 & $* * *$ & 0.1360 & $* * *$ & 0.1360 & $* * *$ \\
\hline & $(0.0379)$ & & $(0.0319)$ & & $(0.0319)$ & \\
\hline Log Income & -0.1504 & $* * *$ & 0.1254 & $* * *$ & 0.1254 & $* * *$ \\
\hline & $(0.0260)$ & & $(0.0158)$ & & $(0.0158)$ & \\
\hline Labor supply & & & & & & \\
\hline Hours & 0.0009 & $* * *$ & 0.0029 & $* * *$ & 0.0029 & $* * *$ \\
\hline & $(0.0006)$ & & $(0.0006)$ & & $(0.0006)$ & \\
\hline & & & & & & \\
\hline McFadden R-squared & 0.374 & & 0.329 & & 0.329 & \\
\hline Log likelihood & -8489.84 & & -9097.459 & & -9097.473 & \\
\hline Total obs & 20381 & & 20381 & & 20381 & \\
\hline
\end{tabular}

Notes: Standard errors in parenthesis. + Significant at $10 \%$. * Significant at $5 \%$. * Significant at $2 \%$.*** Significant at $1 \%$.

Omited variables: Female. Single. Over 65 years old. No completed education. Transportation and other economic sectors. Formal employment (contract) and over 3 minimum salaries.

Original data sources: www.indec.mecon.ar 


\section{APPENDIX 3.1}

Standard Statistics.

Salaried Workers in Bolivia, 2003-2004

\begin{tabular}{|l|c|c|}
\hline \multicolumn{1}{|c|}{ Variable } & Mean & Std. Dev. \\
\hline Pension & 0.1786 & 0.3830 \\
\hline Male & 0.5945 & 0.4910 \\
\hline Married & 0.4886 & 0.4999 \\
\hline Age 14-24 & 0.1773 & 0.3819 \\
\hline Age 25-49 & 0.5998 & 0.4900 \\
\hline Age 50-65 & 0.1628 & 0.3692 \\
\hline Elementary & 0.2038 & 0.4028 \\
\hline Secondary & 0.1427 & 0.3498 \\
\hline Tertiary & 0.2396 & 0.4268 \\
\hline Agriculture & 0.1381 & 0.3450 \\
\hline Construction & 0.0710 & 0.2569 \\
\hline Transport & 0.0604 & 0.2383 \\
\hline Mining & 0.0160 & 0.1254 \\
\hline Manufacture & 0.0532 & 0.2244 \\
\hline Retail & 0.2227 & 0.4160 \\
\hline Government & 0.0386 & 0.1927 \\
\hline Education & 0.0764 & 0.2657 \\
\hline Health Services & 0.0228 & 0.1493 \\
\hline Informality & 0.7731 & 0.4189 \\
\hline Less 1 Ms & 0.7518 & 0.4320 \\
\hline 1 to 2 Ms & 0.0733 & 0.2606 \\
\hline 2 to 3 Ms & 0.0399 & 0.1957 \\
\hline Log Income & 2.2645 & 3.2444 \\
\hline Hours & 44.9618 & 22.7462 \\
\hline
\end{tabular}

\section{APPENDIX 3.2}

PROBIT Estimates in Marginal Effects: Contribution to the New Pension Scheme. Salaried Workers in Bolivia, 2003-2004

\begin{tabular}{|c|c|c|c|c|c|c|}
\hline \multirow{2}{*}{$\begin{array}{ll} & \text { Variable } \\
C & \end{array}$} & \multicolumn{2}{|c|}{ Regression A } & \multicolumn{2}{|c|}{ Regression B } & \multicolumn{2}{|c|}{ Regression C } \\
\hline & -0.5270 & $* * *$ & -0.4727 & $* * *$ & -0.2979 & $* * *$ \\
\hline & $(0.2233)$ & & $(0.1069)$ & & $(0.0894)$ & \\
\hline \multicolumn{7}{|c|}{ Gender and Marital Status } \\
\hline \multirow[t]{2}{*}{ Male } & 0.0943 & $* * *$ & 0.0938 & $* * *$ & 0.0835 & *** \\
\hline & $(0.0497)$ & & $(0.0497)$ & & $(0.0492)$ & \\
\hline \multirow[t]{2}{*}{ Married } & 0.0976 & $* * *$ & 0.0960 & $* * *$ & 0.1378 & $* * *$ \\
\hline & $(0.0484)$ & & $(0.0480)$ & & $(0.0462)$ & \\
\hline \multicolumn{7}{|l|}{ Age } \\
\hline \multirow[t]{2}{*}{ Age 14-24 } & 0.0604 & & & & & \\
\hline & $(0.2165)$ & & & & & \\
\hline \multirow[t]{2}{*}{ Age $25-49$} & 0.2757 & $* * *$ & 0.2220 & $* * *$ & & \\
\hline & $(0.2067)$ & & $(0.0712)$ & & & \\
\hline \multirow[t]{2}{*}{ Age 50-65 } & 0.2724 & $* * *$ & 0.2192 & $* * *$ & 0.0312 & \\
\hline & $(0.2127)$ & & $(0.0907)$ & & $(0.0667)$ & \\
\hline \multicolumn{7}{|l|}{ Education } \\
\hline \multirow[t]{2}{*}{ Elementary } & -0.0142 & & -0.0156 & & -0.0453 & \\
\hline & $(0.0845)$ & & $(0.0843)$ & & $(0.0829)$ & \\
\hline \multirow[t]{2}{*}{ Secondary } & 0.0540 & + & 0.0550 & + & 0.0087 & \\
\hline & $(0.0762)$ & & $(0.0762)$ & & $(0.0741)$ & \\
\hline \multirow[t]{2}{*}{ Tertiary } & 0.2660 & $* * *$ & 0.2663 & $* * *$ & 0.2629 & $* * *$ \\
\hline & $(0.0561)$ & & $(0.0561)$ & & $(0.0559)$ & \\
\hline \multicolumn{7}{|l|}{ Economic Activity } \\
\hline \multirow[t]{2}{*}{ Agriculture } & -0.2011 & $* * *$ & -0.2014 & $* * *$ & -0.2009 & $* * *$ \\
\hline & $(0.1305)$ & & $(0.1302)$ & & $(0.1284)$ & \\
\hline \multirow[t]{2}{*}{ Mining } & 0.2114 & $\star * \star$ & 0.2131 & $\star * *$ & 0.2076 & *** \\
\hline & $(0.1426)$ & & $(0.1426)$ & & $(0.1404)$ & \\
\hline \multirow[t]{2}{*}{ Construction } & -0.2765 & $* * *$ & -0.2758 & *** & -0.2716 & *** \\
\hline & $(0.1360)$ & & $(0.1359)$ & & $(0.1348)$ & \\
\hline \multirow[t]{2}{*}{ Manufacture } & 0.0800 & * & 0.0807 & * & 0.0838 & ** \\
\hline & $(0.0883)$ & & $(0.0882)$ & & $(0.0874)$ & \\
\hline \multirow[t]{2}{*}{ Retail } & -0.0306 & & -0.0305 & & -0.0363 & \\
\hline & $(0.0728)$ & & $(0.0728)$ & & $(0.0724)$ & \\
\hline
\end{tabular}




\section{APPENDIX 3.2}

PROBIT Estimates in Marginal Effects: Contribution to the New Pension Scheme. Salaried Workers in Bolivia, 2003-2004

\begin{tabular}{|l|c|c|c|c|c|c|}
\hline \multicolumn{1}{|c|}{ Variable } & \multicolumn{2}{|c|}{ Regression A } & \multicolumn{2}{c|}{ Regression B } & \multicolumn{3}{c|}{ Regression C } \\
\hline & -0.2912 & $* * *$ & -0.2916 & $* * *$ & -0.2791 & $* * *$ \\
\hline Transport & $(0.1414)$ & & $(0.1416)$ & & $(0.1411)$ & \\
\hline Health Services & 0.3503 & $* * *$ & 0.3494 & $* * *$ & 0.3503 & $* * *$ \\
\hline & $(0.1032)$ & & $(0.1032)$ & & $(0.1023)$ & \\
\hline Education Services & 0.4822 & $* * *$ & 0.4826 & $* * *$ & 0.4787 & $* * *$ \\
\hline & $(0.0779)$ & & $(0.0779)$ & & $(0.0767)$ & \\
\hline Government & 0.3021 & $* * *$ & 0.3023 & $* * *$ & 0.3033 & $* * *$ \\
\hline & $(0.0817)$ & & $(0.0816)$ & & $(0.0813)$ & \\
\hline Labor Condition & & & & & & \\
\hline Informality & -0.8060 & $* * *$ & -0.8062 & $* * *$ & -0.8127 & $* * *$ \\
\hline & $(0.0502)$ & & $(0.0502)$ & & $(0.0497)$ & \\
\hline Labor Supply & & & & & & \\
\hline Hours & 0.0019 & $* * *$ & 0.0019 & $* * *$ & 0.0020 & $* * *$ \\
\hline & $(0.0012)$ & & $(0.0012)$ & & $(0.0012)$ & \\
\hline & & & & & & \\
\hline & & & & & & \\
\hline McFadden R-squared & 0.659 & & 0.659 & & 0.653 & \\
\hline Log Likelihood & -1903.911 & & -1904.164 & & -1936.41 & \\
\hline Total Obs & 11884 & & 11884 & & 11884 & \\
\hline
\end{tabular}

Notes: Standard errors in parenthesis. + significant at $10 \%$ * Significant at $5 \%$. ** Significant at $2 \%$. $* * *$ Significant at $1 \%$.

Omited variables: Female. Single. Over 65 years old. No completed education. Services. Other economic sectors. Formal employment (contract) and over 3 minimum salaries. Original data sources: www.ine.gov.bo

\section{APPENDIX 4.1}

Standard Statistics.

Salaried and Independent Workers in Mexico, 2004

\begin{tabular}{|l|c|c|c|c|}
\hline \multirow{2}{*}{ Variables } & \multicolumn{2}{|c|}{ Salaried } & \multicolumn{2}{c|}{ Independent } \\
\cline { 2 - 5 } & Mean & Std. Dev. & Mean & Std. Dev. \\
\hline Hours & 47.0572 & 15.1919 & 44.7458 & 20.9374 \\
\hline Pension & 0.4116 & 0.4921 & 0.0386 & 0.1928 \\
\hline Male & 0.6483 & 0.4775 & 0.6036 & 0.4892 \\
\hline Married & 0.4884 & 0.4999 & 0.6271 & 0.4836 \\
\hline Age 14-24 & 0.2370 & 0.4253 & 0.0600 & 0.2375 \\
\hline Age 25-49 & 0.6255 & 0.4840 & 0.5910 & 0.4917 \\
\hline Age 50-65 & 0.1201 & 0.3251 & 0.2566 & 0.4368 \\
\hline Elementary & 0.2759 & 0.4470 & 0.4367 & 0.4960 \\
\hline Secondary & 0.4981 & 0.5000 & 0.3215 & 0.4671 \\
\hline Tertiary & 0.1821 & 0.3859 & 0.1083 & 0.3108 \\
\hline Agriculture & 0.0967 & 0.2956 & 0.2299 & 0.4208 \\
\hline Construction & 0.0908 & 0.2873 & 0.0518 & 0.2216 \\
\hline Manufacture & 0.1869 & 0.3899 & 0.1225 & 0.3279 \\
\hline Transport & 0.0464 & 0.2104 & 0.0387 & 0.1930 \\
\hline Retail & 0.1511 & 0.3582 & 0.2852 & 0.4515 \\
\hline Government & 0.0742 & 0.2621 & 0.0123 & 0.1103 \\
\hline Log Income & 3.9068 & 0.4600 & 3.5064 & 0.7131 \\
\hline Informality & 0.4308 & 0.4952 & 0.9469 & 0.2242 \\
\hline Less 1 Ms & 0.1839 & 0.3874 & 0.5162 & 0.4998 \\
\hline 1 to 2 Ms & 0.2552 & 0.4360 & 0.1639 & 0.3702 \\
\hline 2 to 3 Ms & 0.2449 & 0.4300 & 0.1069 & 0.3090 \\
\hline
\end{tabular}




\section{APPENDIX 4.2}

PROBIT Estimates in Marginal Effects: Contribution to the New Pension Scheme. Salaried Workers in Mexico, 2004

\begin{tabular}{|l|c|c|c|c|c|c|}
\hline Variable & \multicolumn{2}{|c|}{ Regression A } & \multicolumn{2}{|c|}{ Regression B } & \multicolumn{2}{|c|}{ Regression C } \\
\hline & -1.7880 & $* * *$ & -3.4585 & $* * *$ & -3.1561 & $* * *$ \\
\hline & $(0.5076)$ & & $(0.3226)$ & & $(0.2539)$ & \\
\hline Gender and Marital Status & & & & & & \\
\hline Married & 0.0826 & $* * *$ & 0.0816 & $* * *$ & 0.0794 & $* * *$ \\
\hline & $(0.0361)$ & & $(0.0360)$ & & $(0.0359)$ & \\
\hline Male & -0.1074 & $* * *$ & -0.1059 & $* * *$ & -0.1061 & $* * *$ \\
\hline & $(0.0376)$ & & $(0.0374)$ & & $(0.0374)$ & \\
\hline Age & & & & & & \\
\hline Age 14-24 & 0.1236 & + & 0.1270 & + & & \\
\hline & $(0.1709)$ & & $(0.1710)$ & & & \\
\hline Age 25-49 & 0.2129 & $* * *$ & 0.2258 & $* * *$ & 0.1060 & $* * *$ \\
\hline & $(0.1668)$ & & $(0.1670)$ & & $0.0438)$ & \\
\hline Age 50-65 & 0.2828 & $* * *$ & 0.2865 & $* * *$ & 0.1628 & $* * *$ \\
\hline & $(0.1715)$ & & $(0.1717)$ & & $(0.0645)$ & \\
\hline Education & & & & & & \\
\hline Elementary & 0.2068 & $* * *$ & 0.2139 & $* * *$ & & \\
\hline & $(0.1323)$ & & $(0.1316)$ & & & \\
\hline Secondary & 0.4445 & $* * *$ & 0.4538 & $* * *$ & 0.2593 & $* * *$ \\
\hline & $(0.1318)$ & & $(0.1311)$ & & $(0.0433)$ & \\
\hline Tertiary & 0.4537 & $* * *$ & 0.4405 & $* * *$ & 0.2445 & $* * *$ \\
\hline & $(0.1378)$ & & $(0.1371)$ & & $(0.0578)$ & \\
\hline Economic Activity & & & & & & \\
\hline Agriculture & -0.4092 & $* * *$ & -0.4329 & $* * *$ & -0.4398 & $* * *$ \\
\hline & $(0.1011)$ & & $(0.1006)$ & & $(0.1003)$ & \\
\hline Construction & -0.3335 & $* * *$ & -0.3329 & $* * *$ & -0.3352 & $* * *$ \\
\hline & $(0.0712)$ & & $(0.0713)$ & & $(0.0712)$ & \\
\hline Transport & -0.1036 & $* * *$ & -0.0940 & $* * *$ & -0.0924 & $* * *$ \\
\hline & $(0.0801)$ & & $(0.0801)$ & & $0.0801)$ & \\
\hline Manufacture & 0.3448 & $* * *$ & 0.3415 & $* * *$ & 0.3444 & $* * *$ \\
\hline & $(0.0468)$ & & $(0.0466)$ & & $(0.0466)$ & \\
\hline Retail & 0.1442 & $* * *$ & 0.1429 & $* * *$ & 0.1448 & $* * *$ \\
\hline & $(0.0498)$ & & $(0.0497)$ & & $(0.0496)$ & \\
\hline & & & & & & \\
\hline
\end{tabular}

\section{APPENDIX 4.2}

PROBIT Estimates in Marginal Effects: Contribution to the New Pension Scheme. Salaried Workers in Mexico, 2004

\begin{tabular}{|c|c|c|c|c|c|c|}
\hline \multirow{2}{*}{$\begin{array}{l}\text { Variable } \\
\text { Government }\end{array}$} & \multicolumn{2}{|c|}{ Regression A } & \multicolumn{2}{|c|}{ Regression B } & \multicolumn{2}{|c|}{ Regression C } \\
\hline & -0.0904 & $* * *$ & -0.0852 & $* * *$ & -0.0874 & $* \star *$ \\
\hline & $(0.0581)$ & & $(0.0581)$ & & $(0.0579)$ & \\
\hline \multicolumn{7}{|l|}{ Labor Condition } \\
\hline \multirow[t]{2}{*}{ Informality } & -0.9135 & $* * *$ & -0.9215 & $\star * *$ & -0.9225 & $* * *$ \\
\hline & $(0.0392)$ & & $(0.0392)$ & & $(0.0391)$ & \\
\hline \multicolumn{7}{|l|}{ Income } \\
\hline \multirow{2}{*}{ Less $1 \mathrm{MS}$} & -0.5282 & $* \star *$ & & & & \\
\hline & $(0.1298)$ & & & & & \\
\hline \multirow[t]{2}{*}{1 to $2 \mathrm{MS}$} & -0.2153 & $* * *$ & 0.0077 & & 0.0074 & \\
\hline & $(0.0711)$ & & $(0.0467)$ & & $(0.0466)$ & \\
\hline \multirow[t]{2}{*}{2 to $3 \mathrm{MS}$} & -0.0829 & $* * *$ & 0.0584 & $\star * *$ & 0.0596 & $\star * \star *$ \\
\hline & $(0.0532)$ & & $(0.0406)$ & & $(0.0406)$ & \\
\hline \multirow[t]{2}{*}{ Log Income } & 0.3611 & $* \star \star$ & 0.7394 & $\star * *$ & 0.7428 & $\star \star \star \star ~$ \\
\hline & $(0.1093)$ & & $(0.0646)$ & & $(0.0644)$ & \\
\hline \multicolumn{7}{|l|}{ Labor Supply } \\
\hline \multirow[t]{2}{*}{ Hours } & 0.0016 & $\star \star \star *$ & 0.0016 & $\star * *$ & 0.0016 & $\star * *$ \\
\hline & $(0.0012)$ & & $(0.0012)$ & & $(0.0012)$ & \\
\hline & & & & & & \\
\hline McFadden R-squared & 0.363 & & 0.360 & & 0.359 & \\
\hline Log Likelihood & -11548.09 & & -11600.62 & & -11611.86 & \\
\hline Total Obs & 26742 & & 26742 & & 26742 & \\
\hline
\end{tabular}

Notes: Standard errors in parenthesis. + significant at $10 \%$ * Significant at $5 \% . * *$ Significant at $2 \%$.*** Significant at $1 \%$.

Omited variables: Female. Single. Over 65 years old. No completed education. Mining financial. Education. Health. Business. Turism and other services. Formal employment (contract) and over 3 minimum salaries.

Original data sources: www.inegi.gob.mx 


\section{APPENDIX 4.3}

ProBIT Estimates in Marginal Effects: Contribution to the New Pension Scheme. Independent Workers Mexico, 2004

\begin{tabular}{|c|c|c|c|c|c|c|c|c|}
\hline \multirow{2}{*}{$\begin{array}{ll} & \text { Variable } \\
C & \end{array}$} & \multicolumn{2}{|c|}{ Regression A } & \multicolumn{2}{|c|}{ Regression B } & \multicolumn{2}{|c|}{ Regression C } & \multicolumn{2}{|c|}{ Regression D } \\
\hline & $x-1.2306$ & *** & -1.6456 & $* * *$ & -0.9098 & *** & -0.4810 & *** \\
\hline & $(0.6871)$ & & $(0.4921)$ & & (0.5395) & & $(0.2496)$ & \\
\hline \multicolumn{9}{|c|}{ Gender and Marital Status } \\
\hline \multirow[t]{2}{*}{ Married } & 0.0449 & & 0.0238 & & 0.0447 & & 0.0385 & \\
\hline & $(0.0781)$ & & $(0.0620)$ & & $(0.0780)$ & & $(0.0773)$ & \\
\hline \multirow[t]{2}{*}{ Male } & -0.0172 & & 0.0794 & $* * *$ & -0.0222 & & -0.0211 & \\
\hline & $(0.0854)$ & & $(0.0687)$ & & $(0.0851)$ & & $(0.0847)$ & \\
\hline \multicolumn{9}{|l|}{ Age } \\
\hline \multirow[t]{2}{*}{ Age $14-24$} & 0.2174 & & 0.1729 & & 0.2167 & & & \\
\hline & $(0.4249)$ & & $(0.3139)$ & & $(0.4271)$ & & & \\
\hline \multirow[t]{2}{*}{ Age $25-49$} & 0.2898 & + & 0.3483 & $* * *$ & 0.2901 & + & 0.1177 & * \\
\hline & $(0.3965)$ & & $(0.2877)$ & & $(0.3987)$ & & $(0.1475)$ & \\
\hline \multirow[t]{2}{*}{ Age 50-65 } & 0.2453 & & 0.2901 & ** & 0.2473 & & 0.0767 & \\
\hline & $(0.4035)$ & & $(0.2937)$ & & $(0.4057)$ & & $(0.1685)$ & \\
\hline \multicolumn{9}{|l|}{ Education } \\
\hline \multirow[t]{2}{*}{ Elementary } & 0.2838 & * & 0.2174 & ** & 0.2844 & * & & \\
\hline & $(0.3190)$ & & $(0.2139)$ & & $(0.3180)$ & & & \\
\hline \multirow[t]{2}{*}{ Secondary } & 0.5591 & **** & 0.5599 & $* * *$ & 0.5552 & $* * *$ & 0.3013 & $* * *$ \\
\hline & $(0.3191)$ & & $(0.2127)$ & & $(0.3183)$ & & $(0.0995)$ & \\
\hline \multirow[t]{2}{*}{ Tertiary } & 0.7002 & *** & 0.7984 & $* * *$ & 0.6872 & *** & 0.4308 & $* * *$ \\
\hline & $(0.3271)$ & & $(0.2210)$ & & $(0.3258)$ & & $(0.1190)$ & \\
\hline \multicolumn{9}{|l|}{ Economic Activity } \\
\hline \multirow[t]{2}{*}{ Agriculture } & -0.1698 & *** & -0.2975 & $* * *$ & -0.1715 & $* * *$ & -0.1902 & $* * *$ \\
\hline & $(0.1517)$ & & $(0.1186)$ & & $(0.1520)$ & & $(0.1510)$ & \\
\hline \multirow[t]{2}{*}{ Construction } & -0.0565 & & -0.1953 & $* * *$ & -0.0533 & & -0.0493 & \\
\hline & $(0.1701)$ & & $(0.1462)$ & & $(0.1692)$ & & $(0.1683)$ & \\
\hline \multirow[t]{2}{*}{ Transport } & -0.0686 & & -0.2569 & $* * *$ & -0.0770 & & -0.0807 & \\
\hline & $(0.1891)$ & & $(0.1641)$ & & $(0.1883)$ & & $(0.1881)$ & \\
\hline Manufacture & 0.0940 & * & 0.0518 & & 0.0930 & * & 0.0908 & * \\
\hline
\end{tabular}

\section{APPENDIX 4.3}

PROBIT Estimates in Marginal Effects: Contribution to the New Pension Scheme. Independent Workers Mexico, 2004

\begin{tabular}{|c|c|c|c|c|c|c|c|c|}
\hline \multirow[t]{2}{*}{ Variable } & \multicolumn{2}{|c|}{ Regression A } & \multicolumn{2}{|c|}{ Regression B } & \multicolumn{2}{|c|}{ Regression C } & \multicolumn{2}{|c|}{ Regression D } \\
\hline & $(0.1035)$ & & $(0.0809)$ & & $(0.1034)$ & & $(0.1027)$ & \\
\hline \multirow[t]{2}{*}{ Retail } & -0.1186 & $* * *$ & -0.2738 & $* * *$ & -0.1182 & $* * *$ & -0.1176 & $* * *$ \\
\hline & $(0.1013)$ & & $(0.0836)$ & & $(0.1011)$ & & $(0.1008)$ & \\
\hline \multirow[t]{2}{*}{ Government } & -0.0612 & & 0.3774 & $\star \star * \star$ & -0.0574 & & -0.0522 & \\
\hline & $(0.1561)$ & & (0.1296) & & $(0.1562)$ & & $(0.1562)$ & \\
\hline \multicolumn{9}{|l|}{ Labor Condition } \\
\hline \multirow[t]{2}{*}{ Informality } & -0.9223 & $* * *$ & & & -0.9280 & $* * *$ & -0.9251 & $* * *$ \\
\hline & $(0.0895)$ & & & & $(0.0893)$ & & $(0.0886)$ & \\
\hline \multicolumn{9}{|l|}{ Income } \\
\hline \multirow[t]{2}{*}{ Less $1 \mathrm{MS}$} & 0.1317 & + & 0.2544 & $* * *$ & & & & \\
\hline & $(0.1737)$ & & $(0.1368)$ & & & & & \\
\hline \multirow[t]{2}{*}{1 to $2 \mathrm{MS}$} & 0.1142 & * & 0.1976 & $* * *$ & 0.0456 & & 0.0468 & \\
\hline & $(0.1318)$ & & $(0.1068)$ & & $(0.0946)$ & & & \\
\hline \multirow[t]{2}{*}{2 to $3 \mathrm{MS}$} & 0.0548 & & 0.0843 & + & 0.0051 & & 0.0068 & \\
\hline & $(0.1358)$ & & $(0.1151)$ & & $(0.1177)$ & & & \\
\hline \multirow[t]{2}{*}{ Log Income } & 0.0426 & & -0.1077 & $* \star *$ & -0.0203 & & -0.0207 & \\
\hline & $(0.1064)$ & & $(0.0792)$ & & $(0.0655)$ & & & \\
\hline \multicolumn{9}{|l|}{ Labor Supply } \\
\hline \multirow[t]{2}{*}{ Hours } & 0.0050 & $* * *$ & 0.0077 & $* * *$ & 0.0050 & $* * *$ & 0.0050 & $* * *$ \\
\hline & $(0.0020)$ & & $(0.0016)$ & & $(0.0020)$ & & & \\
\hline & & & & & & & & \\
\hline McFadden R-squared & 0.544 & & 0.296 & & 0.542 & & 0.540 & \\
\hline Log Likelihood & -734.3124 & & -1132.42 & & -736.1139 & & -740.5657 & \\
\hline Total Obs & 9833 & & 9833 & & 9833 & & 9833 & \\
\hline
\end{tabular}

Notes: Standard errors in parenthesis. + significant at $10 \%$. * Significant at $5 \%$. * Significant at $2 \%$.*** Significant at $1 \%$.

Omited variables: Female. Single. Over 65 years old. No completed education. Mining financial. Education. Health. Business. Turism and other services. Formal employment (contract) and over 3 minimum salaries.

Original data sources: www.inegi.gob.mx 


\section{APPENDIX 5.1}

Standard Statistics.

Uruguay, 2002

\begin{tabular}{|l|c|c|c|c|}
\hline \multirow{2}{*}{ Variable } & \multicolumn{2}{|c|}{ Salaried } & \multicolumn{2}{c|}{ Independent } \\
\cline { 2 - 5 } & Mean & Std. Dev. & Mean & Std. Dev. \\
\hline Hours & 39.4546 & 15.5851 & 37.9226 & 20.3268 \\
\hline Underemployment & 0.1385 & 0.3455 & 0.2472 & 0.4314 \\
\hline Pension & 0.7614 & 0.4262 & 0.3862 & 0.4869 \\
\hline Male & 0.5290 & 0.4992 & 0.6618 & 0.4731 \\
\hline Married & 0.4745 & 0.4994 & 0.5498 & 0.4975 \\
\hline Age 14-24 & 0.1497 & 0.3568 & 0.0796 & 0.2707 \\
\hline Age 25-49 & 0.6175 & 0.4860 & 0.5529 & 0.4972 \\
\hline Age 50-65 & 0.2157 & 0.4113 & 0.3118 & 0.4633 \\
\hline Elementary & 0.5536 & 0.4971 & 0.5559 & 0.4969 \\
\hline Secondary & 0.2449 & 0.4300 & 0.2048 & 0.4036 \\
\hline Tertiary & 0.1460 & 0.3531 & 0.1433 & 0.3504 \\
\hline Agriculture & 0.0313 & 0.1742 & 0.0460 & 0.2096 \\
\hline Construction & 0.0376 & 0.1902 & 0.1268 & 0.3328 \\
\hline Manufacture & 0.1177 & 0.3223 & 0.1458 & 0.3529 \\
\hline Transport & 0.0634 & 0.2437 & 0.0484 & 0.2146 \\
\hline Retail & 0.1418 & 0.3489 & 0.2857 & 0.4518 \\
\hline Government & 0.1200 & 0.3249 & 0.0163 & 0.1268 \\
\hline Log Income & 3.6011 & 0.3834 & 3.5434 & 0.5303 \\
\hline Less 1 Ms & 0.0737 & 0.2612 & 0.1718 & 0.3772 \\
\hline 1 to 2 Ms & 0.1395 & 0.3465 & 0.1852 & 0.3885 \\
\hline 2 to 3 Ms & 0.1710 & 0.3765 & 0.1381 & 0.3450 \\
\hline
\end{tabular}

\section{APPENDIX 5.2}

PROBIT Estimates in Marginal Effects: Contribution to the New Pension Scheme. Salaried Workers in Uruguay, 2002

\begin{tabular}{|c|c|c|c|c|c|c|}
\hline \multirow{2}{*}{$\begin{array}{ll}\text { Variable } \\
C\end{array}$} & \multicolumn{2}{|c|}{ Regression A } & \multicolumn{2}{|c|}{ Regression B } & \multicolumn{2}{|c|}{ Regression C } \\
\hline & -1.1377 & $* * *$ & -2.2734 & $* * *$ & -2.0246 & $* * *$ \\
\hline & $(0.3144)$ & & $(0.1938)$ & & $(0.1702)$ & \\
\hline \multicolumn{7}{|c|}{ Gender and Marital Status } \\
\hline \multirow[t]{2}{*}{ Married } & 0.0977 & $* * *$ & 0.0943 & $* * *$ & 0.0945 & $* * *$ \\
\hline & $(0.0295)$ & & $(0.0294)$ & & $(0.0292)$ & \\
\hline \multirow[t]{2}{*}{ Male } & -0.0922 & $* * *$ & -0.0926 & $* * *$ & -0.0961 & $\star * *$ \\
\hline & $(0.0316)$ & & $(0.0315)$ & & $(0.0314)$ & \\
\hline \multicolumn{7}{|l|}{ Age } \\
\hline \multirow[t]{2}{*}{ Age $14-24$} & 0.1195 & $* * *$ & 0.1228 & *** & -0.0586 & *** \\
\hline & $(0.1013)$ & & $(0.1006)$ & & $(0.0374)$ & \\
\hline \multirow[t]{2}{*}{ Age $25-49$} & 0.1817 & $\star * *$ & 0.1948 & $* * *$ & & \\
\hline & $(0.0965)$ & & $(0.0959)$ & & & \\
\hline \multirow[t]{2}{*}{ Age 50-65 } & 0.1982 & $* * *$ & 0.2077 & $* * *$ & 0.0065 & \\
\hline & $(0.0987)$ & & $(0.0981)$ & & $(0.0351)$ & \\
\hline \multicolumn{7}{|l|}{ Education } \\
\hline \multirow[t]{2}{*}{ Elementary } & 0.1155 & $* * *$ & 0.1137 & $\star * \star$ & & \\
\hline & $(0.0547)$ & & $(0.0541)$ & & & \\
\hline \multirow[t]{2}{*}{ Secondary } & 0.3040 & $* * *$ & 0.3037 & $* * *$ & 0.2019 & *** \\
\hline & $(0.0625)$ & & $(0.0620)$ & & $(0.0358)$ & \\
\hline \multirow[t]{2}{*}{ Tertiary } & 0.4004 & $* * *$ & 0.3979 & $* * *$ & 0.2931 & $* * *$ \\
\hline & $(0.0735)$ & & $(0.0733)$ & & $(0.0535)$ & \\
\hline \multicolumn{7}{|l|}{ Economic Activity } \\
\hline \multirow[t]{2}{*}{ Agriculture } & -0.0275 & & -0.0384 & & -0.0473 & + \\
\hline & $(0.0696)$ & & $(0.0691)$ & & $(0.0687)$ & \\
\hline \multirow[t]{2}{*}{ Construction } & -0.0902 & $* * *$ & -0.0775 & $* * *$ & -0.0744 & *** \\
\hline & $(0.0664)$ & & $(0.0662)$ & & $(0.0660)$ & \\
\hline \multirow[t]{2}{*}{ Transport } & 0.0619 & ** & 0.0600 & $* *$ & 0.0666 & $\star * \star *$ \\
\hline & $(0.0620)$ & & $(0.0622)$ & & $(0.0620)$ & \\
\hline \multirow[t]{2}{*}{ Manufacture } & 0.0502 & $* * *$ & 0.0558 & $* * *$ & 0.0612 & $* * *$ \\
\hline & $(0.0443)$ & & $(0.0442)$ & & $(0.0441)$ & \\
\hline
\end{tabular}




\section{APPENDIX 5.2}

PROBIT Estimates in Marginal Effects: Contribution to the New Pension Scheme. Salaried Workers in Uruguay, 2002

\begin{tabular}{|c|c|c|c|c|c|c|}
\hline \multirow{2}{*}{$\begin{array}{ll} & \text { Variable } \\
\text { Retail } & \end{array}$} & \multicolumn{2}{|c|}{ Regression A } & \multicolumn{2}{|c|}{ Regression B } & \multicolumn{2}{|c|}{ Regression C } \\
\hline & 0.0828 & $\star \star \star *$ & 0.0849 & $* \star \star *$ & 0.0902 & $* \star *$ \\
\hline & $(0.0412)$ & & $(0.0410)$ & & $(0.0409)$ & \\
\hline \multirow[t]{2}{*}{ Government } & 0.5944 & $* * *$ & 0.6290 & $* * *$ & 0.6315 & $* * *$ \\
\hline & (0.0968) & & $(0.0988)$ & & $(0.0987)$ & \\
\hline \multicolumn{7}{|l|}{ Labor Condition } \\
\hline \multirow[t]{2}{*}{ Underemployment } & -0.0931 & $* * *$ & -0.0956 & $* * *$ & -0.0911 & $* * *$ \\
\hline & $(0.0405)$ & & $(0.0401)$ & & $(0.040)$ & \\
\hline \multicolumn{7}{|l|}{ Income } \\
\hline \multirow[t]{2}{*}{ Less $1 \mathrm{MS}$} & -0.4004 & $* * *$ & & & & \\
\hline & $(0.0897)$ & & & & & \\
\hline \multirow[t]{2}{*}{1 to $2 \mathrm{MS}$} & -0.2958 & $* * *$ & -0.1193 & $* * *$ & -0.1187 & $* * *$ \\
\hline & $(0.0546)$ & & $(0.0377)$ & & $(0.0376)$ & \\
\hline \multirow[t]{2}{*}{2 to $3 \mathrm{MS}$} & -0.1491 & $* \star \star$ & -0.0395 & $* \star \star$ & -0.0400 & $* * *$ \\
\hline & $(0.0420)$ & & $(0.0338)$ & & $(0.0337)$ & \\
\hline \multirow[t]{2}{*}{ Log Income } & 0.2775 & $* * *$ & 0.5666 & $* * *$ & 0.5783 & $* * *$ \\
\hline & (0.0799) & & $(0.0496)$ & & (0.0493) & \\
\hline \multicolumn{7}{|l|}{ Labor Supply } \\
\hline \multirow[t]{2}{*}{ Hours } & 0.0051 & $* * *$ & 0.0057 & $* * *$ & 0.0057 & $* * *$ \\
\hline & $(0.0010)$ & & $(0.0010)$ & & $(0.0010)$ & \\
\hline McFadden R-squared & 0.337 & & 0.330 & & 0.326 & \\
\hline Log Likelihood & -5601.640 & & -5664.034 & & -5695.406 & \\
\hline Total Obs & 15381 & & 15381 & & 15381 & \\
\hline
\end{tabular}

Notes: Standard errors in parenthesis. + significant at $10 \%$. * Significant at $5 \%$. ** Significant at $2 \%$.*** Significant at $1 \%$.

Omited variables: Female. Single. Over 65 years old. No completed education. Mining. Financial services. Education. Research. Health. Professional turism and other services. Formal employment and over 3 minimum salaries.

Original data sources: www.ine.gub.uy

\section{APPENDIX 5.3}

PROBIT Estimates in Marginal Effects: Contribution to the New Pension Scheme. Independent Workers in Uruguay, 2002

\begin{tabular}{|c|c|c|c|c|c|c|}
\hline \multirow{2}{*}{$\begin{array}{ll} & \text { Variable } \\
\mathrm{C} & \end{array}$} & \multicolumn{2}{|c|}{ Regression A } & \multicolumn{2}{|c|}{ Regression B } & \multicolumn{2}{|c|}{ Regression C } \\
\hline & -2.0036 & $* * *$ & -1.7085 & $* * *$ & -1.5542 & $* * *$ \\
\hline & $(0.3401)$ & & $(0.2068)$ & & $(0.1832)$ & \\
\hline \multicolumn{7}{|c|}{ Gender and Marital Status } \\
\hline \multirow[t]{2}{*}{ Married } & 0.0885 & $* * *$ & 0.0884 & $* * *$ & 0.0897 & *** \\
\hline & $(0.0408)$ & & $(0.0408)$ & & $(0.0407)$ & \\
\hline \multirow[t]{2}{*}{ Male } & -0.0253 & & -0.0247 & & -0.0301 & + \\
\hline & $(0.0437)$ & & $(0.0437)$ & & $(0.0435)$ & \\
\hline \multicolumn{7}{|l|}{ Age } \\
\hline \multirow[t]{2}{*}{ Age $14-24$} & -0.1023 & * & -0.1034 & * & -0.1560 & $* * *$ \\
\hline & $(0.1251)$ & & $(0.1253)$ & & $(0.0953)$ & \\
\hline \multirow[t]{2}{*}{ Age 25-49 } & 0.0676 & + & 0.0642 & + & & \\
\hline & $(0.0884)$ & & $(0.0883)$ & & & \\
\hline \multirow[t]{2}{*}{ Age $50-65$} & 0.1210 & $\star * \star$ & 0.1176 & $* \star *$ & 0.0492 & $* * *$ \\
\hline & $(0.0897)$ & & $(0.0897)$ & & $(0.0414)$ & \\
\hline \multicolumn{7}{|l|}{ Education } \\
\hline \multirow[t]{2}{*}{ Elementary } & 0.1479 & $* * *$ & 0.1475 & $* * *$ & & \\
\hline & $(0.0803)$ & & $(0.0806)$ & & & \\
\hline \multirow[t]{2}{*}{ Secondary } & 0.3406 & $* * *$ & 0.3418 & $* * *$ & 0.2106 & $* * *$ \\
\hline & $(0.0880)$ & & $(0.0883)$ & & $(0.0473)$ & \\
\hline \multirow[t]{2}{*}{ Tertiary } & 0.6193 & $* * *$ & 0.6195 & $* * *$ & 0.4863 & $* * *$ \\
\hline & $(0.0997)$ & & $(0.0999)$ & & $(0.0656)$ & \\
\hline \multicolumn{7}{|l|}{ Economic Activity } \\
\hline \multirow[t]{2}{*}{ Agriculture } & 0.1264 & $* \star *$ & 0.1303 & $* * *$ & 0.1189 & $* \star \star$ \\
\hline & $(0.0937)$ & & $(0.0936)$ & & $(0.0930)$ & \\
\hline \multirow[t]{2}{*}{ Construction } & -0.3339 & $* * \star$ & -0.3407 & $\star \star \star *$ & -0.3381 & $* * *$ \\
\hline & $(0.0825)$ & & $(0.0821)$ & & $(0.0816)$ & \\
\hline \multirow[t]{2}{*}{ Transport } & 0.1639 & $* * \star$ & 0.1618 & $* \star *$ & 0.1659 & $* * *$ \\
\hline & $(0.0919)$ & & $(0.0918)$ & & $(0.0916)$ & \\
\hline \multirow[t]{2}{*}{ Manufacture } & -0.1087 & $* \star *$ & -0.1086 & $* \star *$ & -0.1051 & $* * *$ \\
\hline & $(0.0624)$ & & $(0.0624)$ & & $(0.0622)$ & \\
\hline
\end{tabular}




\section{APPENDIX 5.3}

PROBIT Estimates in Marginal Effects: Contribution to the New Pension Scheme. Independent Workers in Uruguay, 2002

\begin{tabular}{|c|c|c|c|c|c|c|}
\hline \multirow{2}{*}{$\begin{array}{ll} & \text { Variable } \\
\text { Retail } & \end{array}$} & \multicolumn{2}{|c|}{ Regression A } & \multicolumn{2}{|c|}{ Regression B } & \multicolumn{2}{|c|}{ Regression C } \\
\hline & -0.0893 & 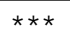 & -0.0929 & $\star * \star *$ & -0.0948 & 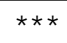 \\
\hline & $(0.0534)$ & & $(0.0534)$ & & $(0.0532)$ & \\
\hline \multirow[t]{2}{*}{ Government } & 0.9312 & $* * *$ & 0.9348 & $* * *$ & 0.9484 & $\star * *$ \\
\hline & $(0.2712)$ & & $(0.2707)$ & & $(0.2699)$ & \\
\hline \multicolumn{7}{|l|}{ Labor condition } \\
\hline \multirow[t]{2}{*}{ Underemployment } & -0.1764 & $* * *$ & -0.1772 & $* * *$ & -0.1697 & *** \\
\hline & $(0.0610)$ & & $(0.0611)$ & & $(0.0607)$ & \\
\hline \multicolumn{7}{|l|}{ Income } \\
\hline \multirow[t]{2}{*}{ Less $1 \mathrm{MS}$} & 0.1205 & $* * *$ & & & & \\
\hline & $(0.1090)$ & & & & & \\
\hline \multirow[t]{2}{*}{1 to $2 \mathrm{MS}$} & -0.0851 & $* * *$ & -0.1409 & $* * *$ & -0.1402 & *** \\
\hline & $(0.0790)$ & & $(0.0605)$ & & $(0.0602)$ & \\
\hline \multirow[t]{2}{*}{2 to $3 \mathrm{MS}$} & -0.0977 & $\star * \star$ & -0.1372 & $* * *$ & -0.1379 & *** \\
\hline & $(0.0679)$ & & $(0.0576)$ & & $(0.0574)$ & \\
\hline \multirow[t]{2}{*}{ Log Income } & 0.3949 & 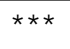 & 0.3238 & $\star * \star *$ & 0.3335 & *** \\
\hline & $(0.0832)$ & & $(0.0517)$ & & $(0.0510)$ & \\
\hline \multicolumn{7}{|l|}{ Labor Supply } \\
\hline \multirow[t]{2}{*}{ Hours } & 0.0052 & $* * *$ & 0.0050 & $* * *$ & 0.0051 & $\star * *$ \\
\hline & $(0.0012)$ & & $(0.0012)$ & & $(0.0012)$ & \\
\hline McFadden R-squared & 0.380 & & 0.379 & & 0.376 & \\
\hline Log Likelihood & -2786.489 & & -2790.312 & & -2804.248 & \\
\hline Total Obs & 6735 & & 6735 & & 6735 & \\
\hline
\end{tabular}

Notes: Standard errors in parenthesis. + significant at $10 \%$. ${ }^{*}$ Significant at $5 \%$. ** Significant at $2 \%$. *** Significant at $1 \%$.

Omited variables: Female. Single. Over 65 years old. No completed education. mining. Financial services. Education. Research. Health. Professional turism and other servi-

ces. Formal employment and over 3 minimum salaries.

Original data sources: www.ine.gub.uy

\section{REFERENCES}

Abel, A. (1986), "Capital Accumulation and Uncertain Lifetimes with Adverse Selection”, Econometrica, Vol. 54, No. 5, pp. 1079-1098.

Águila, G. E. (2005), "Ahorro privado, reforma de pensiones y modelo de ciclo de vida. Evidencia del IMSS para analizar el caso mexicano", Consar, www.consar.gob. $\mathrm{mx} /$ convocatoria_2007/index.html

Arenas de Mesa, A., and F. Bertranou (2005), "Previsión social: ¿Reformular o consolidar el modelo mixto?", in ILo, Uruguay: Empleo y protección social, de la crisis al crecimiento, pp. 397-421.

Auerbach, P., M. E. Genoni and C. Pages (2005), "Social Security Coverage and Labor Markets in Developing Countries", Working Paper 537, IDB.

Bertranou, F. (ed.) (2001), Cobertura previsional: Argentina, Brasil y Chile, ILO.

Crabbe, C. A., (ed.) (2005), A Quarter Century of Pension Reform in Latin America and the Caribbean: Lessons Learned and Next Steps, Sustainable Development Department, IDB.

De la Rica, S., and T. Lemieux (1993), "Does Public Health Insurance Reduce Labor Market Flexibility or Encourage Underground Economy? Evidence from Spain and the United States", wP 4402, NBER.

Enriquez, F. R. (2005), "Sostenibilidad fiscal y balance generacional: La situación de Mexico y los efectos de reformar el sistema de pensiones", Consar, www.consar.gob.mx/convocatoria_2007/index.html

Feldstein, M., and E. Ranguelova (2001), "Individual Risk in an Investment-Based Social Security System", The American Economic Review, Vol. 91, No. 4, pp. 1116-1125.

Forteza, A., and N. Ferreira-Coimbra (2004), Protección Social en Uruguay: Financia miento, cobertura y desempeño 1990-2002, ILO.

Gallardo, R. (2006), "Risk Management and individual Accounts-Pension Scheme: The Mexican Case, Biwako Journal of Economics, Vol. 4, No. 1, pp. 26-40.

(2007), "An Assessment on the Pension Reforms in Latin America: Individual Participation in the Pension Schemes in Mexico and Uruguay", International Public Economy Studies, Vol. 18.

Gustman, A. L., O. Mitchell and T. Steinmeier (1994), "The Role of Pensions in the Labor Market: A Survey of the Literature", Industrial and Labor Relations Review, Vol. 47, No. 3, pp. 417-428.

Holzmann, R., T. Packard and J. Cuesta (2001), "Extending Coverage in Multipillar Pension Systems: Constraints and Hypotheses, Preliminary Evidence and Future 
Research Agenda", in Holzmann, R., and J.E. Stiglitz (eds.), New Ideas About Old age Security, The World Bank, pp. 452-493.

Holzmann R., and J.E. Stiglitz (eds.) (2001), New Ideas About Old Age Security, The World Bank.

International Labor Organization (ILO) (2005), Uruguay: Empleo y protección social, de la crisis al crecimiento.

James, E. (1997), "Pension Reform: Is there any Efficiency-Equity Tradeoff?", paper presented at the conference: "Inequality Reducing Growth in Latin America's Market Economies“, The World Bank.

Mesa-Lago, C. (2001), "Reassessing Pension Reform in Chile and Other Countries in Latin America”, International Social Security Review, No. 54:4, pp 67-92.

(2002), "Myth and Reality of Pension Reform: the Latin American evidence", World Development, Vol. 30, No. 8, pp.1309-1321.

(2005), "Evaluation of a Quarter Century of Structural Pension Reforms in Latin America", in Crabbe, C. A. (ed.), A Quarter Century of Pension Reform in Latin America and the Caribbean: Lessons

Mitchell, O. (1996), "Social Security Reform in Uruguay: An economic assessment", Pension Research Council, PRC WP, p. 20.

Murai, T. (2004), "The Foundation of the Mexican Welfare State and Social Security Reform in the 1990s", The Developing Economies, XLII-2, pp. 262-287.

Queisser, M. (1999), "Pension Reform: Lessons from Latin America", Policy Brief No. 15, OECD Development Center.

Rofman, R. (2005), "Social Security Coverage in Latin America", social protection discussion paper, No. 0523, World Bank.

Rosen, S. (1986), “The Theory of Equalizing Differences”, Handbook of Labor Economics, Chapter 12, University of Chicago.

Sheshinski, E., and Y. Weis (1981), "Uncertainty and Social Security Systems", The Quarterly Journal of Economics, Vol. 96, No. 2, pp. 189-206.

Stiglitz, J., and P. Orszag (1999), "Rethinking Pension Reforms: 10 Myths About Social Security Systems", World Bank conference: "New ideas about old age security”. Also in Holzmann, R., and J. E. Stiglitz (eds.), 2001, New Ideas About old age Security, The World Bank, pp.17-56.

Von Gersdorff, H. (1997), "Pension Reform in Bolivia", Policy Research Working Paper 1832, The World Bank.

\section{La forma triangular de la matriz de Leontief}

Alberto Benitez*

\section{RESUMEN}

En este artículo presento algunos comentarios sobre la forma triangular del modelo de Leontief. Entre ellos, propongo una demostración alternativa de la equivalencia entre la existencia de una solución viable para el modelo y la condición de Hawkins y Simon (H-S). Además, expongo el peculiar significado económico de los coeficientes de la diagonal principal en la forma triangular de la matriz de Leontief, lo cual permite, entre otras cosas, apreciar la estrecha relación entre las condiciones económicas y las matemáticas en la solución del modelo. También identifico algunas proposiciones matemáticas equivalentes a (H-S) que poseen interés económico.

Número de clasificación: JEL: C390, C670.

Palabras clave: Leontief, Hawkins and Simon, insumo-producto, matriz no negativa.

\section{Abstract}

In this article, I present some comments related to the triangular form of Leontief's system. Among them, I propose an alternative proof of the equivalence between the existence of viable solutions to the model and the Hawkins and Simon's condition (H-S). In addition, I expose the peculiar economic significance of the coefficients in the principal diagonal of the triangular form of Leontief's matrix, which permits us, among other things, to appreciate the tight relation between the economic and the mathematical conditions in the solution to the model. Moreover, I identify some other mathematical propositions equivalent to $(\mathrm{H}-\mathrm{S})$ possessing economic interest.

Classification number: JEL: C390, C670.

Key words: Leontief, Hawkins and Simon, input-output, non-negative matrices.

* Profesor de Economía de la Universidad Autónoma Metropolitana, Unidad Iztapalapa. Correo electrónico: besa@xanum.uam.mx. 